\title{
COMMUNICATION IN FRENCH FOREIGN LANGUAGE LEARNING BY IMPLEMENTING THE ASPECTS OF INTERCULTURALITY
}

\author{
This research paper examines the case study and the weak sides of the implementation of intercultural education in a FLT class, and then \\ examines how such teaching could be effective. The didactic intervention through which the native teacher was reflexive was done in two stages \\ in order to recover all the didactic aspects necessary for a successful implementation in the future. \\ Keywords: interculturality, aspects, french, teaching, process, communication
}

\section{Introduction}

In this paper, we deal with teaching French by the aid of selected aspects of interculturality, promoting intercultural approach in multicultural foreign language education. In the European Centre for Modern Languages in Graz (Institution of the Council of Europe), the intercultural approach belongs among pluralistic approaches and is described in the FREPA - Framework of reference for Pluralistic Approaches [1, 2]. During the research phase, we proceeded by means of the content qualitative pre analysis and by the aid of the indirect observation (video records and analysis of students and teacher's talk observation sheet. Pluralistic approaches to teaching languages and cultures are new didactic trends in language policy. The general aim of the pluralistic approaches implemented into the school subjects is to create and develop language and cultural consciousness in order to construct and enrich self - plurilingual intercultural competence. Students need to communicate [3, 4], to live and to socialise in multicultural and multilingual contexts $[5,6]$. Within the learning process, learners are to develop their plurilingual and pluricultural knowledge, skills and attitudes through designed pluralistic approaches described in the mentioned document. Globalization and integration process opens new opportunities, types and forms of communication, the existence of which is impossible without mutual understanding between different cultures [7]. Global changes in the information, communication, professional and other spheres have determined qualitatively new areas of the education system [8].
This paper examines the disadvantages, risks and weak sides of the implementation of intercultural education in a FLT class, and then examines how such teaching could be effective. The didactic intervention through which the native teacher was reflexive [9] was done in two stages in order to recover all the didactic aspects necessary for a successful implementation in the future. For the similar methodology procedures or teaching theories see as well [10 - 22].

\section{Research procedure}

Initially, the native teacher EVG prepared an interesting course on the subject of discrimination. The chosen song with which he planned to work is called "The Difference" from the performer Salif Keita. The song considered a hymn to love for peace and tolerance is part of the album bearing the same name of Salif Keïta released on November 16, 2009 at Emarcy. In 2010, the album whose song is dedicated to the evocation in Africa of its albino condition was rewarded with a Victory of the music during the ceremony of the Victories of the music 2010 in the category "Album of world music of the Year ". The teacher prepared a work with the words of the song adapted for teaching purposes. By means of a sheet, the pupils had to identify the missing words while reflecting on their understanding of the words of the song.. The teacher then prepared a list of questions concerning racism in Africa and in general. According to the didactic intervention and the analyses of the course, it is obvious that this ambitious objective was not reached during the course. And that is the

\footnotetext{
* Jana Birova, Dinara G. Vasbieva, Alfiya R. Masalimova

Department of Romance Languages and Literatures, Faculty of Education, Comenius University, Bratislava, Slovakia Foreign Languages Department, Financial University under the Government of the Russian Federation, Moscow, Russia Kazan (Volga region) Federal University, Russia

Email: jana.birova@uniba.sk
} 
objective of this paper - to present negative points in order to avoid them in future implementations and in order to make students communicate more in foreign language.

Educational Objectives: Recognizing Discrimination, Responding to Racism

Cognitive linguistic objectives: recognize the words in the song, express attitudes towards the discussed subject

Number of students: 16

Location: Piarist grammar school, Slovakia

Material: text of the song, teacher brainstorming questions Instructions and support: see annexe A

\subsection{Research methods}

To verify the effectiveness, we used qualitative content analysis method as well as indirect observation method (video analysis) as well as a quantitative method for counting teacher's talk and students' talk.

\section{Results}

\subsection{Qualitative content pre - analysis of the lesson objectives by means of the descriptors FREPA ${ }^{1}$}

These FREPA descriptors were assigned to evaluate the class and lesson objectives:

\section{Knowledge:}

K 2.6 Has knowledge about historical facts (linked to relations between nations or people, resettlements of people) which have influenced or do influence the appearance or development of certain languages

K 4.3 Possesses knowledge about the history of languages (e.g. the origin of some languages, some lexical and phonological evolutions, etc.)

K 6.7 Knows that words may be constructed differently in different languages

K 8.6 Knows that each culture determines or organises at least partly the perception of the world or way of thinking of its members

K 8.6.1 Knows that facts, behaviours or speech may be perceived or understood differently by members of different cultures

$\mathrm{K}$ 8.6.2 Is familiar with some schemes of interpretation specific to certain cultures as far as knowledge of the world is concerned (e.g. numbering, methods of measurement, ways of telling time, etc.)

K 8.7 Knows that cultures influence behaviours, social practices or personal evaluations (of oneself or of others)

$\mathrm{K}$ 8.7.1 Is familiar with some social practices or customs from different cultures

${ }^{1}$ http://frepa.ecml.at
$\mathrm{K}$ 8.7.1.1 Is familiar with some social practices or customs from neighbouring cultures

$\mathrm{K}$ 8.7.2 Is familiar with some specificities of one's own culture in relation to certain social practices or customs from other cultures K 9 Knows that cultural diversity and social diversity are closely linked

K 9.1 Knows that a culture is always complex and is itself made up of (more or less) different conflicting or convergent subcultures K 9.2 Knows that within the same culture there exist cultural subgroups corresponding to social, regional or generational sub - populations

$\mathrm{K}$ 9.2.1 Knows some examples of the variation of cultural practices according to social, regional or generational groupings $\mathrm{K}$ 9.2.2 Knows (in one's own culture or in other cultures) some norms related to social practices and which are specific to certain social, regional or generational groupings

$\mathrm{K} 10$ Knows the role of culture in intercultural relations and communication

K 10.1 Knows that uses, norms or values specific to each culture make behaviour or personal decisions complex within a context of cultural diversity

K 10.3 Knows that cultural differences may underlie verbal or non - verbal communication or interaction

$\mathrm{K}$ 10.3.1 Knows that difficulties in communication caused by cultural differences may result in cultural shock or cultural fatigue $\mathrm{K} 10.4$ Knows that intercultural relations and communication are influenced by knowledge or representations one has of other cultures and those that others have of one's own culture

$\mathrm{K}$ 10.4.1 Knows that knowledge one has of cultures often includes stereotypes (i.e. a simplified and sometimes useful way of grasping one aspect of reality, liable to lead to oversimplification and generalisation)

K 10.4.2 Knows some stereotypes of cultural origin which may affect intercultural relations and communication

$\mathrm{K}$ 10.4.3 Is aware of the existence of cultural prejudice

K 10.4.3.1 Knows some examples of prejudice or misunderstandings of cultural origin (especially in the case of the cultures of those communities whose language one is learning)

$\mathrm{K}$ 11.1.3 Knows that history or geography often offer one the opportunity to understand or explain certain cultural practices or values

$\mathrm{K}$ 11.1.3.1 Knows certain historical facts (linked to relations between nations or people, to migrations, etc.) or geographical facts which have influenced or influence the creation or evolution of certain cultures

K 12 Knows several phenomena relative to the diversity of cultures $\mathrm{K} 12.1$ Knows that there is (still) a great multiplicity of cultures all over the world

K 12.5 Knows that the diversity of cultures does not imply superiority or inferiority of any one in relation to the others $\mathrm{K}$ 12.5.1 Knows that relations between countries are often unequal or hierarchised 
K 12.5.2 Knows that hierarchies established arbitrarily between cultures change with time

K 13.2.3 Knows some resemblances or differences between the cultures of different social, generational or regional groups

$\mathrm{K} 14.1$ Knows that identity is constructed on different levels (e.g. social, national, supranational, etc.)

Attitudes:

A 2 Sensitivity to the existence of other languages, cultures or persons or to the existence of linguistic, cultural or human diversity

A 2.1 Sensitivity towards one's own language or culture and other languages or cultures

A 2.2 Sensitivity to linguistic or cultural differences

A 2.2.1 Being aware of different aspects of language or culture which may vary from language to language or from culture to culture

A 2.4 Being sensitive both to differences and to similarities between different languages or cultures

A 2.5.1 Being sensitive to (or aware of) the linguistic or cultural diversity of society

A 4 Positive acceptance of linguistic or cultural diversity, of others or of what is different

A 4.2 Accepting the fact that another language or culture may function differently from one's language or culture

A 4.5 Acceptance (or recognition) of the importance of all languages or cultures and the different places they occupy

A 5.1 Empathy with (openness to) alterity or otherness

A 5.3.3 Openness towards the unfamiliar (linguistic or cultural)

A 5.3.3.1 Being open (and mastering one's own eventual resistances) to what seems incomprehensible and different

A 6 Respect or regard for "foreign" or "different" languages, cultures or persons; for the linguistic, cultural or human diversity of the environment; for linguistic, cultural or human diversity as such (in general)

A 6.1 Respect for differences and diversity (in a plurilingual and pluricultural environment)

A 6.2 Valuing (or appreciating) linguistic or cultural contacts

A 6.4 Considering all languages as equal in dignity

A 6.5 Having respect for human dignity and equality of human rights for everybody

A 6.5.1 Respecting (or valuing) each individual's language and culture

A 6.5.2 Considering each language or culture as a means of human development, of social inclusion and as an indispensable condition in the exercise of citizenship

A 7 Disposition or motivation with respect to linguistic or cultural diversity or plurality

A 7.3.4 Readiness to experience a threat to one's identity (or to feel loss of individuality)

A 7.3.5 Readiness to be considered as an outsider
A 7.5 Motivation to study or compare the functioning of different languages (e.g. structures, vocabulary, systems of writing, etc.) or cultures

A 8 A wish or a will to be involved or to act in connection with linguistic or cultural diversity or plurality or in a plurilingual or pluricultural environment

A 8.1 Determination to take up the challenge of linguistic or cultural diversity (going beyond simple tolerance, towards deeper levels of understanding and respect, towards acceptance)

A 8.5 A wish to discover other languages, cultures or peoples

A 8.5.1 A wish to encounter other languages, cultures or peoples linked to the personal or family history of persons one knows

A 8.6.2 The will to try to understand the differences in behaviour, in values or in attitudes of members of the receiving culture

A 8.8 The will to learn from others (their language or their culture)

A 11.2 Disposition to suspend judgement about one's own culture or other cultures

A 11.3 The will to combat (deconstruct or overcome) one's prejudices towards other languages or cultures and their speakers or members

A 11.3.1 Being attentive to one's own negative reactions towards cultural or linguistic differences (e.g. fears, contempt, disgust, superiority, etc.)

A 11.3.2 Being ready to adopt attitudes to diversity which conform to knowledge one may acquire or may have acquired from it

A 12 Disposition to starting a process of linguistic or cultural decentring or relativising

A 12.4 Disposition to reflect on the differences between languages or cultures and on the relative nature of one's own linguistic or cultural system

A 19.1 Disposition to modify one's own knowledge or representations of the learning of languages when these appear to be unfavourable to learning (negative prejudice)

Skills:

S 1.8 Can analyse the cultural origins of certain behaviours

S 1.9 Can analyse specific social phenomena as being the consequence of cultural difference

S 1.10 Can develop a system of interpretation which enables one to perceive the particular characteristics of a culture (e.g. meanings, beliefs, cultural practices, etc.)

S 2.9 Can identify (or recognise) communicative variations engendered by cultural differences

S 2.10 Can identify (or recognise) specific forms of behaviour linked to cultural differences

S 2.11 Can identify (or recognise) cultural prejudice

S 3.2.4 Can compare languages aurally

S 3.3 Can perceive proximity or distance between graphic forms S 3.10.2 Can perceive differences or similarities in different aspects of social life (e.g. living conditions, working life, participation in activities of charities, respect for the environment, etc.) 
Table 1 A who - talks references

\begin{tabular}{|c|c|}
\hline $\begin{array}{l}\text { Who } \\
\text { talks }\end{array}$ & $\Sigma$ \\
\hline $\mathrm{Tt}$ & $\Sigma$ Tt 14 minutes 15 \\
\hline St & $\Sigma$ St 11 minutes 49 out of which: \\
\hline El 1 & $\begin{array}{l}0^{\prime} 01+0^{\prime} 08+0^{\prime} 14=0^{\prime} 25+0^{\prime} 48 \text { de prière }+4^{\prime} 05 \text { of listening } \\
\text { activities }=5^{\prime} 18\end{array}$ \\
\hline El 2 & $\begin{array}{l}0^{\prime} 02+0^{\prime} 02=0^{\prime} 04+0^{\prime} 48 \\
\text { de prière }+4^{\prime} 05 \text { of listening activities }=4^{\prime} 57\end{array}$ \\
\hline El 3 & $0^{\prime} 04+0^{\prime} 48$ de prière $+4^{\prime} 05$ of listening activities $=4^{\prime} 57$ \\
\hline $\mathrm{El} 4$ & $\begin{array}{l}0^{\prime} 01+0^{\prime} 07=0^{\prime} 08+0^{\prime} 48 \text { de prière }+4^{\prime} 05 \\
\text { of listening activities }=5^{\prime} 01\end{array}$ \\
\hline El 5 & $0^{\prime} 19+0^{\prime} 48$ de prière $+4^{\prime} 05$ of listening activities $=5^{\prime} 12$ \\
\hline El 6 & $0^{\prime} 12+0^{\prime} 48$ de prière $+4^{\prime} 05$ of listennig activities $=5^{\prime} 05$ \\
\hline El 7 & $\begin{array}{l}0^{\prime} 06+0^{\prime} 03+0^{\prime} 09+0^{\prime} 05=0^{\prime} 23+0^{\prime} 48 \text { praying }+4^{\prime} 05 \\
\text { of listening activities }=5^{\prime} 16\end{array}$ \\
\hline El 8 & $0^{\prime} 00+0^{\prime} 48$ de prière $+4^{\prime} 05$ of listening activities $=4^{\prime} 53$ \\
\hline El 9 & $0^{\prime} 00+0^{\prime} 48$ de prière $+4^{\prime} 05$ of listening activities $=4^{\prime} 53$ \\
\hline El 10 & $0^{\prime} 00+0^{\prime} 48$ de prière $+4^{\prime} 05$ of listening activities $=4^{\prime} 53$ \\
\hline El 11 & $0^{\prime} 00+0^{\prime} 48$ de prière $+4^{\prime} 05$ of listening activities $=4^{\prime} 53$ \\
\hline El 12 & $0^{\prime} 00+0^{\prime} 48$ de prière $+4^{\prime} 05$ of listening activities $=4^{\prime} 53$ \\
\hline El 13 & $0^{\prime} 00+0^{\prime} 48$ de prière $+4^{\prime} 05$ of listening activities $=4^{\prime} 53$ \\
\hline El 14 & $0^{\prime} 00+0^{\prime} 48$ de prière $+4^{\prime} 05$ of listening activities $=4^{\prime} 53$ \\
\hline El 15 & $0^{\prime} 00+0^{\prime} 48$ de prière $+4^{\prime} 05$ of listening activities $=4^{\prime} 53$ \\
\hline El 16 & $0^{\prime} 00+0^{\prime} 48$ de prière $+4^{\prime} 05$ of listening activities $=4^{\prime} 53$ \\
\hline
\end{tabular}

S 3.10.3 Can compare meanings or connotations corresponding to cultural features (e.g. a comparison of the concept of time, etc.) S 3.10.4 Can compare different cultural practices

S 7.7 Can manage one's own learning in a reflective manner.

It is assumed that the activity develops several sub - competencies of the intercultural plurilingual competence described in the Framework of reference for pluralistic approaches document. It is up to the teacher to conduct his course in order to develop the listed knowledge, attitudes, and skills.

\subsection{Analysis of the filmed class sequences}

The effectiveness of the FLT class and of the students' performance (communication) centred on the implementation of intercultural aspects into the FLT class (by the aid of the concept called discrimination) was counted by the equation: $\Sigma \mathrm{Tt}: \Sigma \mathrm{St}$

The following abbreviations were used:

- teacher (native speaker - French): EVG

- Slovak teacher (observer): EJS

- student/s: El/s.

It means that

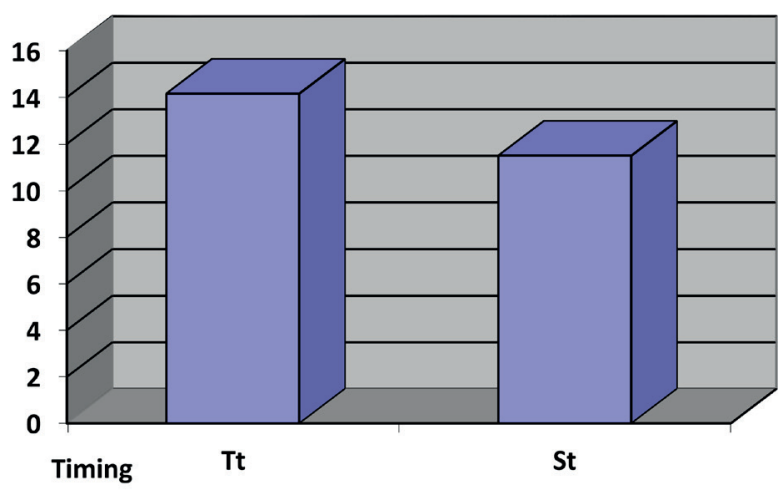

Figure 1 Proportion of talks

$\Sigma \mathrm{Tt}: \Sigma \mathrm{St}$

$\Sigma 14^{\prime} 15: \Sigma 11^{\prime} 49$

$\mathrm{Tt}>\mathrm{St}$

- the class is effective if $\mathrm{Tt}<\mathrm{St}$

- the class is a little effective or not effective if $\mathrm{Tt} \geq \mathrm{St}$.

The $\mathrm{Tt}$ is the teacher's talk (speech of professor) and the St is the student's talk or students' talk. Thus it is possible to summarize all the statements of the teacher, all the statements of a chosen student, but also all the statements of all the students together. We sum up a total number of seconds of talk (see Table 1).

To count the teacher's talk and the students' talk in minutes (30 minutes of class), this means that:

- the class is not effective if $\mathrm{Tt} \geq 15$ minutes (a half of class)

- the class is a little effective if $\mathrm{Tt}=8$ up to 15 minutes

- the class is effective if $\mathrm{Tt} \leq 8$ minutes.

\subsection{Research results}

The very first results during the research procedure occurred when measuring the time of students' individual talk and the talk of the teacher. The total students' talk was 11 minutes 49 seconds which was counted on the base of summarizing partial - individual students' talk. The teacher's talk was higher than students' talk. The following graph was made up from the measured values.

\section{The graph on the proportion of talks}

Total minutes of the Educational Discourse Tt versus total minutes activities and student talk St is shown in Figure 1.

The class was a little effective.

The graph of the timing of student activities and talk during the class shows in Figure 2.

Five students performed weakly and the last 5 ones were even weaker. 


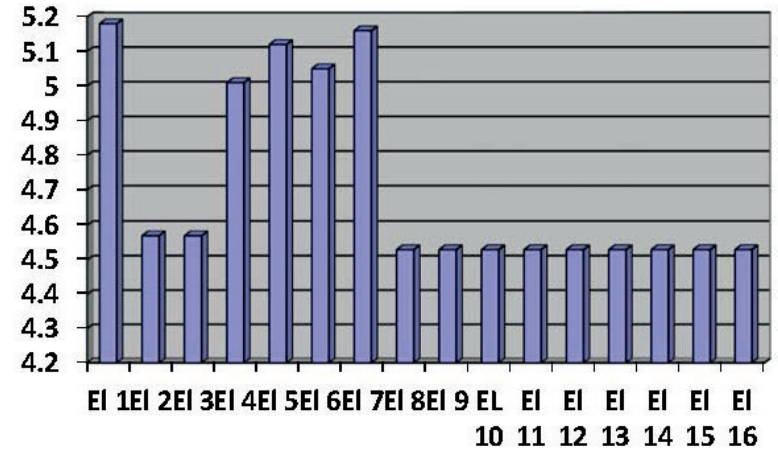

Figure 2 Students' talk and activity proportion

\section{Discussion and conclusions}

As first, the teacher's techniques were observed. EVG prepared a beautiful song that deals with an important phenomenon but little known in the country of Slovakia: the Albino theme in Africa. The teacher could have first presented the theme or done an icebreaker activity related to racism. The song, itself very important for the theme of racism, did not meet with the understanding among the young Slovak public on any level educational, cultural or linguistic one. The teacher could have distributed a support material to each student in the class in order to facilitate the listening activity as the class lasted only 30 minutes. The song lasted itself about 5 minutes (that is a fifth of the course to pass the song) is considered as not much effective. Similarly, the fact that at the end, the song followed in a completely unknown language did not increase the students' interest or motivation.

In terms of lesson management, the teacher asks the students if they hear well. He acts in this way during the listening phase and so disturbs them during their comprehension activity. $\mathrm{He}$ then moves the computer and places it in front of the first student sitting in the first row. Loud sound was only available for students in the first row and the second row, the others were without the possibility to listen to the song properly. As a consequence, they talked.

Two other listening exercises that the teacher develops prove to be little effective. He only passes them halfway because he sees that the class would soon finish. During the post - listening activity, he discovers that most of the students did not fill in the blanks in the material distributed by the teacher. The teacher avoids these students and stops at the student who filled an item in a wrong way saying:

\section{Video Excerpt 1:}

"Eh, non, c'est l'opposé. Je suis dans noir. » (line 33, 34 of Indirect observation sheet)
In the teacher's talk that follows, the teacher concentrates mainly on the grammatical items:

\section{Video Excerpt 2 :}

«Et le deuxième mot, tu l'as peut - être aussi... Ma peau est » (line 36 of Indirect observation sheet)

Reply of the student 2 - El 2 : «Blanc» (line 37 of Indirect observation sheet)

«Mais au féminin ? Qui a le blanc au féminin ? Blanc au féminin? Blanc. Blanche. (lines 38, 39 of Indirect observation sheet)

Reply of the student 1 - El 1: "Blanche » (line 40 of Indirect observation sheet)

\section{Video Excerpt 3 :}

«C'est la différence qui est jolie. Et comment tu écris « joli »à la fin ? « joli » (lines 54, 55 of Indirect observation sheet)

«Eh non. Eh, le féminin c'est juste le - e. le masculin c'est juste joli. (EVG writes on the blackboard " joli » and « $\mathrm{M}$ » which means « masculin » and « $\mathrm{F}$ » which means « féminin ».) C>est masculin... donc, ca s'écrit avec un - e a la fin parceque c'est féminin et au masculin, c'est juste - i. (lines 58 - 62 of Indirect observation sheet)

The teacher only explains two grammatical rules which third grade students already tackled during their first - year courses. These explanations are very undeveloped and do not serve to encourage students to work deeper. The teacher could have prepared a series of exercises or activities in order to satisfy the linguistic or communication need of the students. No work has been done there.

Concerning the oral production or expression of opinions by the students or the taking of the position vis - a - vis racism, we find in the class one sentence expressed and repeated by two students.

\section{Video Excerpt 4 :}

«Ce n'est pas bien. » (lines 120, 121 of Indirect observation sheet)

The majority of the class had problems with the song comprehension. This was true in relation to the theme and in relation to the change of the codes (French and Banbarras) without knowing what the albino means. A large part of the class, students read the same text by stopping a few parts to illuminate the spelling. The activities of the students during the FFT intercultural class entitled "Discrimination" consist of reading the song, passively listening to the song and repeating the prayer at the beginning of the course (Catholic High School). This leads to the conclusion that students have not been exposed to a productive language activity. Most of the students did not understand the tasks of the course.

In summary, according to the mathematical analyses of the total pedagogical discourse and the totality of the students' talk 
and students' activities and according to the qualitative analyses of these discourses, we sum up that the class was ineffective.

\section{Acknowledgement}

The study is the partial result of the project VEGA $1 / 0106 / 15$ 2015-2017 "Teoreticke skumanie a empiricke overenie konceptu interkulturnej komunikativnej kompetencie ako sucasti aktualnej koncepcie vyucby cieoovych jazykov v sucinnosti so Spolocnym europskym referencnym ramcom pre jazyky: ucenie, vyucovanie, hodnotenie", and the partial result of the international cultural educational project Enseignement du francais dans le contexte linguolittéraire financed by University Ageny for Francophony, 2017.

\section{References}

[1] CANDELIER, M., et al.: Le CARAP, Un Cadre de Reference Pour les Approches Plurielles des Langues et des Cultures (in Franch) [online]. Conseil de 1'Europe, CELV, Austria, 2011. Available: http://carap.ecml.at.

[2] CANDELIER, M., et al: Banque de Materiaux Didactiques (BMD)/Teaching Materials Bank. 132 cards [online]. 2009. Available: http://carap.ecml.at.

[3] ZARATE, G.: Enseigner Une Culture Etrangere (in Franch). Hachette, Paris, 1986

[4] WIDDOWSON, H. G.: Aspects of Language Teaching. Oxford University Press, Oxford, 1991.

[5] BYRAM, M.: Teaching and Assessing Intercultural Communicative Competence. Multilingual Matters, Clevedon, Philadelphia, 1997.

[6] Cadre Europeen Commun de Reference Pour les Langues: Enseigner, Apprendre, Evaluer. Conseil de l'Europe, Didier, 2001.

[7] FAITA, D., VIEIRA, M.: Reflexions Methodologiques Sur l'Autoconfrontation Croisee (in Franch). Skhole, 10(1), 57-68, 2003.

[8] VASBIEVA, D. G., KALUGINA, O. A.: An Analysis of Students' Intercultural Competence Levels in a Non - Linguistic Higher School. XLinguae, 9(3), 58-69, 2016.

[9] VASBIEVA, D. G.: A Lean Approach as a Means of Achieving Communicative Competence. XLinguae, 7(4), 75 -82, 2014.

[10] GONDOVA, D.: The Development of Speaking Skills in English Language Lessons. Communications - Scientific Letters of the University of Zilina, 14(1), 23-28, 2012.

[11] VINSONNEAU, G.: Culture et Comportement (in Franch). Armand Colin, France, 2000.

[12] WIERZBICKA, A.: Cross - Cultural Pragmatics: The Semantics of Human Interaction. Mouton de Gruyter, Berlin, New York, 2003.

[13] CABAnOVA, V.: Social Attitudes and Values of Young People in the Context of Multicultural Education. Communications Scientific Letters of the University of Zilina, 16(3), 4-8, 2014.

[14] HANESOVA, D.: Move Toward Learner - Centred Foreign Language Pedagogy: Focusing on Factors Fostering Language Intake. XLinguae, 8(4), 46-59, 2015.

[15] HANESOVA, D. NELSON, A., BADLEY, K.: Educators in Search of the Fine Line between Use and Misuse of the Technologies. Communications - Scientific Letters of the University of Zilina, 19(1), 44-48, 2017.

[16] KHAN, N. N., KOLUMBAYEVA S. Z., KARSYBAYEVA R. K., NABUOVA R. A., KURMANBEKOVA, M. B., SYZDYKBAYEVA, A. D.: Evaluation of the Program Effectiveness of Research Competence Development in Prospective Elementary School Teachers. International Journal of Environmental and Science Education, 11(18), 12299-12316, 2016.

[17] BORISOVA, O. V., VASBIEVA, D. G., MALYKH, N. I., VASNEV, S. A., BIROVA, J.: Problem of Using Innovative Teaching Methods for Distance Learning Students. International Electronic Journal of Mathematics Education, 11(5), 1175-1184, 2016.

[18] KRALOVA, Z., BAKAY - ZAHORSKA, M., CINCIBEAUX, N. H.: The Historical Background of the Slovak Press in the USA. Communications - Scientific Letters of the University of Zilina, 16(3), 36-40, 2014.

[19] WACHTARCZYKOVA, J.: Who/What is Today Referred to as a Grey Eminence? (in Slovak), Slovenska rec, 79(3-4), 194-199, 2014.

[20] BERESOVA, J.: Methodology of Teaching English (in Slovak). MPC, Bratislava, 2009.

[21] BERESOVA, J.: Intercultural Communication - Its Irreplaceable Role in Teaching English and in Pregradual and Postgradual Teacher Training (in Slovak). Adamcova, L. (Ed.), Cudzie jazyky a medzikulturna komunikacia, Z - F LINGUA, Bratislava, 2011.

[22] ZAGIDULliNA, D. F., AMINEVA, V. R.: Avant - Garde Research in the Field if Verse Forms (Based on I. Yuzeev Lyrics). Xlinguae, 9(1), 2016. 
Annexe A

Dans la chanson retrouvez les mots lacunaires.

La Différence

Je suis un noir

Ma peau est 1

Et moi j'aime 2.

C'est La Différence qui est jolie

Je suis un blanc

Mon sang est noir

Et moi j'adore a

C'est La Différence qui est 3

Je voudrais

Que nous nous entendions dans l'amour

Que nous nous comprenions dans l'amour et dans la paix

(Refrain) $\mathrm{x} 2$ :

La vie sera belle $\mathrm{x} 3$

Chacun a son tour aura son amour

La vie sera belle $\mathrm{x} 3$

Chacun dans l'honneur

Aura son 4

La vie sera belle
D finai bai

D dj1

D kagni

D magni

O bai y couleur kaon ka gnyoro dafa

(Refrain)

Ny y bai $n$ fai

Y y n ka fima fai

Fima bai $n$ fai

$\mathrm{N}$ fin $\mathrm{d}$

Ny y bai $n$ fai

Y y n ka djmai fai

Djmain bai $\mathrm{n}$ fai

$\mathrm{N}$ djl do

Ny fina

A li yr kai bachi y

Allah y fima dai

Djma dai kan ka gnorota kan ka gnoro dafa

(Refrain) x3

Clé : 1 blanche, 2 bien, 3 jolie, 4 bonheur

Annexe B

Indirect observation class sheet

\begin{tabular}{|c|c|c|c|}
\hline Timing & Line & $\begin{array}{l}\text { Who } \\
\text { talks/ who } \\
\text { performs }\end{array}$ & Interactions \\
\hline \multirow[t]{9}{*}{$00^{\prime} 24$} & 1 & EJS & Este raz vas poprosim. Veci - odlozte si vsetko. Pero, zosit (class management) \\
\hline & 2 & & \\
\hline & 3 & El 1 & Ja tam sedim. \\
\hline & 4 & EJS & Aj tak vies, daj si to von na chodbu. \\
\hline & 5 & El 6 & Dam si to do tasky. Take mam mokre gate. \\
\hline & 6 & EJS & Tam si ich daj, neboj ja ti ich budem strazit. Lubosko, len pero si zober. \\
\hline & 7 & & \\
\hline & 8 & El 4 & Jasne, idem. A zosit treba? \\
\hline & 9 & EJS & Dole si daj tu tasku. \\
\hline \multirow[t]{2}{*}{$01^{\prime} 05$} & 10 & EJS & Bonjour à tous. Comme habituellement, debout s'il vous plait. \\
\hline & 11 & & \\
\hline $022^{\prime} 02$ & 12 & Els & Au nom du père et du fils. Notre père... (students praying) \\
\hline \multirow[t]{6}{*}{$02 ' 50$} & 13 & EJS & C'est Vincent qui va travailler avec vous aujourd'hui. \\
\hline & 14 & EVG & Vous aimez la chanson, non? Vous aimez chanter? On va faire une petite chanson à l'ordi. Eh, vous \\
\hline & 15 & & avez... \\
\hline & 16 & & Ça sera juste des paroles. Vous écoutez d'abord et (EVG passes the song). Vous entendez là ? \\
\hline & 17 & & \\
\hline & 18 & El 4 & Plus volume \\
\hline
\end{tabular}




\begin{tabular}{|c|c|c|c|}
\hline & $\begin{array}{l}19 \\
20 \\
21\end{array}$ & & $\begin{array}{l}\text { (EVG changes the place of computer, computer is now installed in front of the student in the first row. } \\
\text { Students listen to the song without lyrics.) }\end{array}$ \\
\hline 07'07 & $\begin{array}{l}22 \\
23 \\
24 \\
25 \\
26 \\
27 \\
28 \\
29 \\
30 \\
31 \\
32\end{array}$ & EVG & $\begin{array}{l}\text { Vous avez compris un peu la chanson ? Non ? La fin de la chanson c'est normal, c'est en africain. C'est } \\
\text { en banbarras, une langue du Mali. Donc la fin de la chanson, c'est normal que vous avez pas compris. } \\
\text { Le début c'est en francais. Quelques mots vous avez compris? Ou l'ensemble est... qui a compris un } \\
\text { petit peu, la chanson? (students whisper) Personne? Eh, on va la réécouter et je vais vous donner le } \\
\text { texte qu'il faudra compléter. Les paroles. (EVG distributes to students the lyrics adapted for the class } \\
\text { work) ... } \\
\text { Vous complétez les paroles, vous allez entendre ... (students fill in the gaps.) }\end{array}$ \\
\hline $10^{\prime} 25$ & $\begin{array}{l}33 \\
34\end{array}$ & EVG & (EVG controls what students fill in) Eh, non, c'est l'opposé. Je suis dans noir. \\
\hline & 35 & El 2 & Noir \\
\hline $10^{\prime} 47$ & 36 & EVG & Et le deuxième mot, tu l'as peut - être aussi... Ma peau est \\
\hline $10^{\prime} 49$ & 37 & E1 2 & Blanc \\
\hline $10^{\prime} 50$ & $\begin{array}{l}38 \\
39\end{array}$ & EVG & Mais au féminin? Qui a le blanc au féminin? Blanc au féminin? Blanc. (students whisper) Blanche. \\
\hline $\begin{array}{l}11^{\prime} 12 \\
11^{\prime} 22\end{array}$ & $\begin{array}{l}40 \\
41 \\
42\end{array}$ & $\begin{array}{l}\text { El } 1 \\
\text { EVG }\end{array}$ & $\begin{array}{l}\text { Blanche. } \\
\text { Qui veut lire après? Je suis un noir, ma peau est blanche. Et moi, ... qui veut lire? Oliver? La troisième } \\
\text { ligne... }\end{array}$ \\
\hline $\begin{array}{l}11^{\prime} 40 \\
11^{\prime} 52\end{array}$ & $\begin{array}{l}43 \\
44 \\
45 \\
46\end{array}$ & $\begin{array}{l}\text { El } 1 \\
\text { EVG }\end{array}$ & $\begin{array}{l}\text { Et moi, j'aime bien ça. C'est la différence qui est jolie. } \\
\text { Quelqu'un a les mots qui suivent après? (EVG passes the song for the third time.) Vous réécoutez une } \\
\text { autre fois... (El } 3 \text { sneezes.) }\end{array}$ \\
\hline $13^{\prime} 29$ & 47 & Els & Na zdravie. \\
\hline 14 '14 & $\begin{array}{l}48 \\
49\end{array}$ & EVG & Est - ce que vous avez réussi à trouver d'autres mots? Je suis un blanc et mon sang est ... \\
\hline $14^{\prime} 21$ & 50 & Élèves & Noir \\
\hline $14^{\prime} 22$ & 51 & EVG & Parfait \\
\hline $14^{\prime} 26$ & 52 & EVG & Qui veut lire la suite? Qui veut lire? \\
\hline $14^{\prime} 30$ & 53 & El 3 & Et moi, j'adore ça. C'est la différence, c'est qui est jolie. \\
\hline 14 '34 & $\begin{array}{l}54 \\
55\end{array}$ & EVG & C'est la différence qui est jolie. Et comment tu écris « joli » à la fin? « joli » \\
\hline $14^{\prime} 42$ & $\begin{array}{l}56 \\
57\end{array}$ & El 5 & Chod to napisat, ako si to napisala. (El 3 writes on the blackboard « joliee», EVG corrects.) \\
\hline $15^{\prime} 01$ & $\begin{array}{l}58 \\
59 \\
60 \\
61 \\
62 \\
63\end{array}$ & EVG & $\begin{array}{l}\text { Eh non. Eh, le féminin c'est juste le - e. le masculin c'est juste joli. (EVG writes on the blackboard } \\
\text { « joli » et « } \mathrm{M} \text { » which means «masculin » and « } \mathrm{F} \text { » which means « féminin ».) C'est masculin... } \\
\text { donc, ça s'écrit avec un - e a la fin parce que c'est féminin et au masculin, c'est juste - i. Qui veut lire le } \\
\text { quatrième paragraphe? Je voudrais... qui veut le lire? }\end{array}$ \\
\hline $15^{\prime} 36$ & $\begin{array}{l}64 \\
65 \\
66\end{array}$ & El 6 & $\begin{array}{l}\text { (El } 6 \text { reads the text.) Je voudrais que nous nous entendions dans l'amour, que nous nous comprenions } \\
\text { dans l'amour et dans la paix. }\end{array}$ \\
\hline $15^{\prime} 48$ & 67 & EVG & Et qui veut lire le cinquième paragraphe, le dernier? \\
\hline
\end{tabular}




\begin{tabular}{|c|c|c|c|}
\hline $15^{\prime} 50$ & $\begin{array}{l}68 \\
69\end{array}$ & El 7 & $\begin{array}{l}\text { La vie est belle, chacun à son tour aura son amour, la vie sera belle. (Elève } 7 \text { reads the song } \\
\text { paragraph.) }\end{array}$ \\
\hline $15^{\prime} 56$ & $\begin{array}{l}70 \\
71 \\
72 \\
73 \\
74 \\
75 \\
76 \\
77 \\
78 \\
79 \\
80\end{array}$ & EVG & $\begin{array}{l}\text { Et maintenant est - ce que vous comprenez toute la chanson? Est - ce que vous connaissez Salif Keita? } \\
\text { C'est un chanteur malien. (EVG works on computer, shows a photo of an Albino.) Si vous savez, ceci } \\
\text { est un Albinos. C'est lui. (EVG shows it to the students sitting on the first row.) Il est Albinos. Vous } \\
\text { savez qu'est - ce que c'est pour les animaux? Par exemple un ours albinos. C'est une maladie de la peau, } \\
\text { par exemple. Les ours voilà. Ils sont blancs. Et lui, il est noir et sa peau est noire. (EVG shows the } \\
\text { phenomenon of Albinos to other students.) }\end{array}$ \\
\hline $17^{\prime} 28$ & $\begin{array}{l}81 \\
82 \\
83\end{array}$ & & $\begin{array}{l}\text { (EVG shows the photo of the singer Salif Keita; students sitting on the first and second row are able to } \\
\text { see the photo, not others.) }\end{array}$ \\
\hline $17 ' 48$ & $\begin{array}{l}84 \\
85 \\
86 \\
87 \\
88 \\
89 \\
90\end{array}$ & EVG & $\begin{array}{l}\text { Et est - ce que vous savez pourquoi il chante cette chanson - là ? Est - ce que vous savez pourquoi il } \\
\text { chante cette chanson - là, le titre de la chanson c'est La différence. Le titre de la chanson c'est La } \\
\text { différence, est - ce que vous savez pourquoi il chante cette chanson - là? Est - ce que vous avez vu déjà } \\
\text { beaucoup des albinos? (élèves chuchotent). Et les Africains blancs? }\end{array}$ \\
\hline $18^{\prime} 34$ & 91 & EJS & Tu as déjà vu? \\
\hline $18^{\prime} 36$ & 92 & El 7 & Non. Je n'ai vu pas. \\
\hline $18 ' 41$ & $\begin{array}{l}93 \\
94\end{array}$ & EJS & Je n'ai jamais vu. Et, est - ce que tu penses qu'il y en a beaucoup? Ou non? \\
\hline $18^{\prime} 49$ & $\begin{array}{l}95 \\
96\end{array}$ & El 7 & Ze Ci si myslim, ze ich je vela? (El 7 asks in Slovak). Non. Je ne pense pas qu'ils sont beaucoup. \\
\hline $18^{\prime} 58$ & $\begin{array}{l}97 \\
98 \\
99 \\
100 \\
101 \\
102 \\
103 \\
104 \\
105 \\
106 \\
107 \\
108 \\
109 \\
110\end{array}$ & EVG & $\begin{array}{l}\text { Non ils sont pas beaucoup. Au Mali, ils doivent etre } 1000 \text { à - peu - près. Une mille au Mali à - peu - } \\
\text { près et euh, il doit avoir } 6 \text { - } 7 \text { millions d'habitants. Si c'est, je pense, si c'est } 6 \text { - } 7 \text { millions d'habitants, } \\
\text { ils doivent être mille sur l'ensemble de la population. Donc, ils sont rejetés. Est - ce que tu sais ce que } \\
\text { c'est « rejetés » ? Racisme, le racisme. Ils sont vicimes de racismes. (Some students get bored and } \\
\text { talk.) ... noire, puisqu'ils sont blancs. Donc le racisme n'est pas comme en France' les blancs envers les } \\
\text { noirs. Vous avez compris? (students sitting without performing anything.) Qu'est - ce que tu n'as pas } \\
\text { compris? Vsetko? (El } 2 \text { laughs.) eh, le racisme, c'est souvent les blancs, une personne blanche envers } \\
\text { les noirs, ou les gypses avec blancs envers les gypses. Alors que en Afrique c'est souvent le noir }\end{array}$ \\
\hline 20 '16 & $\begin{array}{l}111 \\
112 \\
113\end{array}$ & $\begin{array}{l}\text { El } 1 \\
\text { EVG } \\
\text { El } 1\end{array}$ & $\begin{array}{l}\text { On sa nafarbi. } \\
\text { Hm? En francais } \\
\text { Ehm. (students laugh) }\end{array}$ \\
\hline 20 '29 & $\begin{array}{l}114 \\
115 \\
116\end{array}$ & EVG & $\begin{array}{l}\text { En Afrique c'est l'inverse qu'en Europe, les racistes ils sont surtout noirs. Ils n'aiment pas les personnes } \\
\text { blanches. (EJS explains.) }\end{array}$ \\
\hline
\end{tabular}




\section{kom Nikcole}

\begin{tabular}{llll}
\hline $20^{\prime} 48$ & 117 & El 1 & Vincent! \\
$21^{\prime} 05$ & 118 & EVG & Qu'est - ce que vous pensez du racisme? C'est bien? C'est mauvais? Qu'est - ce que vous en pensez? \\
& 119 & & \\
& 120 & El 7 & Ce n'est pas bien. \\
& 121 & El 4 & Ce n'est pas bien. \\
\hline
\end{tabular}

